\title{
DOES THE PREVENTION OF ILLEGAL EVICTION FROM AND UNLAWFUL OCCUPATION OF LAND ACT OF 1998 PROVIDE ADEQUATE FAMILY HOME PROTECTION TO INSOLVENT DEBTORS OR IS IT STILL PIE IN THE SKY? (PART 1)
}

\author{
André Boraine \\ Blur LLB LLM LLD \\ Faculty of Law, University of Pretoria
}

\section{SUMMARY}

Although some legal systems provide some protection of the homestead or family home for the debtor when his or her estate is insolvent, such direct protective measures are absent in South African insolvency law. Such protection during insolvency can be provided by means of some level of exemption of the family home or homestead of the insolvent like in the insolvency laws of the USA, or by providing protection of occupancy to the insolvents and his or her dependants as is the case in England and Wales.

In view of the developments in light of the right to housing as provided for in section 26 of the Constitution concerning the protection of the primary residence of a debtor in South African individual debt collecting and execution procedures, the question will be posed in Part 1 of this article if the same principles should apply in the case of a court hearing an application for compulsory sequestration, especially if the debtor raises the point that the sequestration order may render him or her homeless, should also be considered by such court. In this respect, no direct authority for this proposition could be found yet. (Commentators have argued for some time that the position of the homestead of the debtor in insolvency needs attention of the legislature as well but there has not been real progress in this regard to date.)

However, there are a few judgments where the applicability of the Prevention of Illegal Eviction from and Unlawful Occupation of Land Act 19 of 1998 (the PIE Act) after sequestration of the insolvent's estate has been considered. Part 2 of the article will therefore be devoted to discuss developments in this regard and to consider what problems are encountered in applying the PIE Act during insolvency of the debtor and also if this Act provides sufficient protection to insolvent debtors to prevent them from being evicted from "their" homes where they cannot afford alternative accommodation.

Against this background, the two parts of the article deal with different aspects of the issue under discussion. Ultimately the two parts are thematic to provide some answers to the pertinent question, namely if the PIE Act can provide effective interim and/or adequate protection to an insolvent debtor who may be evicted from his or her (former) homestead - in particular in the absence of direct measures in insolvency 
law, which protect insolvents and their dependants under these circumstances. In raising this question pertinent issues regarding the application of the PIE Act in insolvency also will be considered.

\section{INTRODUCTION}

As briefly discussed below in a case of the insolvency of a debtor some legal systems provide a level of protection of the homestead or family home. Such protection can be achieved either by means of excluding or exempting the homestead or some percentage or amount of its equity from the insolvent estate's assets or by allowing the insolvent and his or her dependants to continue to occupy the property for a certain period and/ or until they find alternative accommodation. South African law, however, does not provide any direct protection in insolvency law.

Within the ambit of individual debt collecting and execution procedures the South African courts have developed a certain amount of protection for consumer debtors in this regard by applying section 26 of the South African Constitution in relation to the applicable attachment and execution rules. In brief, this protection entails a judicial discretion to be exercised before the primary residence of a debtor is attached with a view to selling it in execution. In the event of relevant circumstances the court, exercising such discretion, may refuse to declare the primary residence especially executable. These measures do not apply to the sequestration process as such, although alternative measures such as debt relief in terms of the National Credit Act ${ }^{1}$ in some instances may be of assistance. Commentators have argued for some time that the position of the homestead of the debtor in insolvency needs attention of the legislature as well but there has not been real progress in this regard to date. ${ }^{2}$ Part 1 of this article will therefore consider the background and will offer some answers to the applicability of section 26 of the Constitution during the application for compulsory sequestration.

There are a few cases, however, where the Prevention of Illegal Eviction from and Unlawful Occupation of Land $\mathrm{Act}^{3}$ featured after sequestration of the insolvent estate. The main aim of this article therefore is to consider pertinent aspects arising from the PIE Act and to determine what protection it can provide insolvent debtors to prevent them from being evicted from "their" homes where they cannot afford alternative accommodation. (This aspect will mainly be discussed in Part 2 of the article.)

Act 34 of 2005. See further in general on the National Credit Act Scholtz, Otto, Van Zyl, Van Heerden and Campbell Guide to the National Credit Act (2019 update) 12-197 ff; Otto and Otto The National Credit Act Explained 3ed (2015) par 30.9.

2 See for instance Steyn Statutory Regulation of Forced Sale of the Home in South Africa (doctoral thesis, University of Pretoria) $2012586 \mathrm{ff}$; Steyn "Treatment of a Debtor's Home in Insolvency: Comparative Perspectives and Potential Developments in South Africa" 2013 International Insolvency Law $144 \mathrm{ff}$; Van Heerden, Boraine and Steyn "Perspectives on Protecting the Family Home in South African Insolvency Law" in Omar International Insolvency Law: Reforms and Challenges (2013) $227 \mathrm{ff}$; and Evans "Does an Insolvent Debtor Have a Right to Adequate Housing" 2013 SA Merc LJ $119 \mathrm{ff}$.

3 Act 19 of 1998 (PIE Act or PIE). 
In order to deal with this issue the article will consider case law relevant to the discussion and salient aspects of the PIE Act against a brief background of the legal position in the USA and England, the development of homestead protection within the ambit of individual execution procedures in South Africa and relevant aspects and consequences of a sequestration order.

It is now a fact that the PIE Act also finds application in the post sequestration phase of an insolvent estate and a number of judgments have emanated from this development. This article, however, is not intended to provide a comprehensive discussion of the PIE Act as such but discusses features and issues relating to the Act and its application in insolvency law.

Four judgments in particular inspired the theme of the article. ABSA Bank $v$ Murray ${ }^{4}$ serves as an early and important example where the PIE Act was applied in the after sequestration phase and where the insolvents raised reasons why they should not be evicted from the homestead. In Botha NO v Kies $^{5}$ the Court noted that the defences (perhaps rather the protective measures) of the PIE Act may be availed by an insolvent debtor faced with an eviction order by the trustee under particular circumstances. The court found in Body Corporate of Redberry Park v Sukude $N O{ }^{6}$ an application for compulsory sequestration, that the applicant had not established that there would be advantage to creditors if the debtor's property is sold in execution, and it appeared to the court that the wish to circumvent the provisions of the PIE Act motivated the application for sequestration (relative to the eviction of persons from the dwelling unit). The Supreme Court of Appeal in the judgment of Mayekiso v Patel NO considered various aspects of the PIE Act that may be relevant in a sequestration situation. In this case the insolvents raised among others, defences provided for in the PIE Act in an attempt to extend their occupation of the family homestead.

Against the contextualised background provided above, the question is considered if the PIE Act can provide effective interim and/or adequate protection to an insolvent debtor who may be evicted from his or her (former) homestead - in particular in the absence of direct measures in insolvency law that protect insolvents and their dependants under these circumstances. In raising this question pertinent issues regarding the application of the PIE Act in insolvency will also be considered.

2004 (2) SA 15 (CPD).

Unreported case no 40111 of 2012 (GP).

[2015] JOL 33408 (KZD).

2019 (2) SA 522 (WCC). 


\section{BRIEF COMPARATIVE NOTES ON THE AMERICAN AND ENGLISH HOMESTEAD PROTECTION MEASURES ${ }^{8}$}

\section{General}

It is important to note that some insolvency systems make provision for the protection of the homestead or family home. ${ }^{9}$ This protection is achieved either by excluding such home or some of the equity therein from the insolvent estate or by protecting the continued occupancy by the insolvent and his or her spouse and dependants. These protective measures are based on policy considerations and are driven by socio-economic factors peculiar to a particular society. For the purposes of this article a few salient aspects of the American and English approaches to the protection of the family homestead will be considered, but by no means is it a comprehensive comparative study of these systems.

\section{United States of America}

The United States insolvency law largely is codified in the Federal Bankruptcy Code of 1978 as amended by the Bankruptcy Abuse Prevention and Consumer Protection Act of 2005. ${ }^{10}$ Bankruptcy for a consumer debtor can be initiated in terms of Chapter 7 of the Bankruptcy Code that amounts to "straight bankruptcy", the liquidation of the non-exempt estate assets, or by a repayment plan in terms of Chapter 13 .

As far as homestead protection is concerned the Code, in principle, provides for an exemption of the property used as the primary residence of the insolvent in relation to the extent that it is not mortgaged. ${ }^{11}$ The exemption also relates to movable property used for residential purposes like a mobile home or trailer. ${ }^{12}$

Where a state has not opted-out of the federal bankruptcy law in relation to exemptions section 522 of the Bankruptcy Code applies so as to exempt a prescribed amount etcetera regarding the primary residence. ${ }^{13}$ Currently, the exemption amount in terms of the federal law is $\$ 25.510,00$. The consequence of this rule is that the equity in the homestead is exempt up to

8 See Steyn Statutory Regulation of Forced Sale of the Home in South Africa ch 7 for a consideration of the prevalent legal positions in the USA, UK, Canada and New Zealand; Steyn 2013 International Insolvency Review (IIR) $146 \mathrm{ff}$; Van Heerden, Boraine and Steyn in Omar International Insolvency Law: Reforms and Challenges $233 \mathrm{ff}$; and Evans 2013 SA Merc LJ $124 \mathrm{ff}$.

9 See Steyn Statutory Regulation of Forced Sale of the Home in South Africa ch 7; Steyn 2013 IIR 144.

10 Abbreviated as BAPCPA.

11 Ferriel and Janger Understanding Bankruptcy 3ed (2013) 416 and 417.

12 Ibid.

$13 \S 522(d)(1)$, US Bankruptcy Code 1978, as amended by BAPCPA. This amount has been set to be increased since 2010 and subsequently every three years so as to reflect inflation as determined by the U.S. Department of Labor's Consumer Price Index; see Ferriel and Janger Understanding Bankruptcy 417. 
the prescribed amount but not the homestead itself. Where a state opted-out it may prescribe its own exemption rules pertaining to the primary residence resulting in a variety of options and exemptions operating in the USA. The amount of the homestead exemption in some states is simply too small however to permit the debtor to keep his home ${ }^{14}$ but at least permits a debtor to keep a portion of the proceeds of the sale of his or her home. ${ }^{15}$ The value of the exemption varies between states; Texas and Florida, for instance, are rather "liberal" in their approach and basically have no cap on the value of a homestead that may be exempted by their residents. ${ }^{16}$ In Texas the homestead exemption has no dollar value limit as such but is limited to a 10 acre exemption for an urban homestead and a 100 acre exemption for a rural homestead.

Ferriel and Janger ${ }^{17}$ provide a practical example, where the insolvent's home is worth $\$ 100000,00$ but is subject to a mortgage of $\$ 75000,00-$ then the insolvent holds equity of $\$ 25000,00$ in that house. It may be that the applicable exemption in a particular state is $\$ 15000,00$, in which case this amount is exempt from the insolvent estate. When it comes to the distribution of the proceeds the mortgagee in principle will get the mortgaged amount of $\$ 75000,00$, the insolvent may keep the exempt amount of $\$ 15000,00$ and the balance of $\$ 10000,00$ is used to be distributed to other creditors. In order to keep the home the insolvent must reach a deal with the mortgagee as well as the trustee. Where financially possible for the insolvent for instance, it can be done by refinancing or via the reaffirmation of the debt with the mortgagee, as well as by selling other exempt property to assist in this regard. This scenario seems to be more prevalent when the debtor files for a Chapter 13 repayment plan in terms of the Bankruptcy Code than in a straight bankruptcy provided for in Chapter $7 .{ }^{18}$

The differences in the exemption rules of the various states have been summarised as follows: ${ }^{19}$

- Some states provide $100 \%$ exemption while others provide little or none. ${ }^{20}$

- In some states married couples may double the protected exempt amount, while in others not.

- In some states you need to file a declaration of homestead before filing for bankruptcy but in others the protection is an automatic consequence of filing.

14 Ferriel and Janger Understanding Bankruptcy 416-417.

15 Ibid. Since many States have opted-out of the Federal provision the amount of the homestead exemption varies from one State to another.

16 Ibid.

17 Ferriel and Janger Understanding Bankruptcy 417.

18 Ibid.

19 See Asset Protection Planning "Homestead Exemptions by State and by Territory" https://www.assetprotectionplanners.com/planning/homestead-exemptions-by-state/ (accessed 2020-01-20).

20 Asset Protection Planning https://www.assetprotectionplanners.com/planning/homesteadexemptions-by-state/ and see the table provided with the exempt amounts in the various states which have adopted their own exemption rules. 
- Although the majority of states, which have opted-out of the federal rules and the debtor, must follow the state exemption rules, some states afford the debtor with an option to choose between federal and the state's exemption rules.

It should be noted that the important 2005 amendments to the Bankruptcy Code, among others section 522(b)(3)A of the Bankruptcy Code, were enacted in order to discourage debtors from relocating to another state with a more favourable dispensation in this regard shortly before filing for bankruptcy.

To summarise, the general principle in the USA is that the primary homestead or a portion of the equity in it may be exempt from the insolvent estate of the debtor but since states may opt-out of the exemption in the Federal Bankruptcy Code the specific rules differ from state-to-state.

\section{England and Wales ${ }^{21}$}

Currently, in the English system, there are various rules to protect the family home or an interest in such property both in insolvency as well as outside the realm of formal insolvency or bankruptcy. ${ }^{22}$ The position regarding the protection of the family home or the continued occupation of it depends on whether or not the debtor formally had been declared bankrupt. In prebankruptcy it will be considered if it is reasonably possible for the debtor to rectify any default with a view to keeping the house.

The point of departure of bankruptcy is that the bankrupt estate consists of all the property belonging to or vested in the bankrupt at the commencement of bankruptcy. ${ }^{24}$ Since "property" is defined broadly so as to include every description of property or interest, the (family) home also in principle forms part of the estate. This circumstance is relevant where the insolvent (bankrupt) jointly owns a house, for instance with a spouse or partner since both then hold a beneficial interest in such property. In terms of section 306 of the Insolvency Act, 1996 the bankrupt's home is also property that vests in the trustee on his or her appointment and who then has an obligation to realise its value for the benefit of the creditors.

Where the property consists of an interest in a house, which at the date of bankruptcy is the sole or principal residence of the bankrupt and the spouse or former spouse of the bankrupt in general the trustee has a three-year time limit, calculated from the date of the bankruptcy order, to sell the property in

21 See Steyn Statutory Regulation of Forced Sale of the Home in South Africa $460 \mathrm{ff}$; Steyn 2013 IIR 144; Van Heerden, Boraine and Steyn in Omar International Insolvency Law: Reforms and Challenges $227 \mathrm{ff}$; Fletcher The Law of Insolvency 5ed (2014) $221 \mathrm{ff}$; Seally and Milman Annotated Guide to the Insolvency Legislation 7ed (2003) $359 \mathrm{ff}$.

22 Steyn 2013 IIR 154 refers to the Administration of Justice Acts of 1970 and 1973 that allow a court to stay or suspend execution against a mortgaged property which is a dwellinghouse where it appears likely within a reasonable period to pay the sums due or to remedy any other default. See also Steyn Statutory Regulation of Forced Sale of the Home in South Africa $460 \mathrm{ff}$; Fletcher The Law of Insolvency $221 \mathrm{ff}$; Seally and Milman Annotated Guide to the Insolvency Legislation $359 \mathrm{ff}$ regarding the position in England and Wales.

23 See in general the Administration of Justice Acts of 1970 and 1973.

24 See s 283(a) of the Insolvency Act, 1996. 
terms of section 283A of the Insolvency Act, $1996 .{ }^{25}$ Fletcher indicates that the beneficial interest of the non-bankrupt spouse or partner of the bankrupt attaches to the proceeds of the sale. ${ }^{26}$ The beneficial interest of the bankrupt may be sold to the spouse or partner of the bankrupt. This interest, however, may be lost to the estate should the trustee fail to realise it within the threeyear period in which case it reverts to the bankrupt.

Broadly speaking, a distinction is drawn between a case where the debtor is the sole owner of the property ${ }^{27}$ and where the home is owned jointly by the debtor and his spouse or civil partner. ${ }^{28}$ Various statutes may be applicable, depending on the particular situation and on so-called "home rights" that are enacted in the Family Law Act, $1996 .{ }^{29}$ The Insolvency Act, $1986^{30}$ provides for a general protection of occupancy in the family home for a 12 month period in bankruptcy but a further postponement may be allowed in exceptional circumstances. ${ }^{31}$ Where an order is made after this 12 month period the court will assume, unless the circumstances of the case are exceptional, that the interests of the creditors outweigh all other circumstances. ${ }^{32}$

In essence, and where the bankrupt is entitled to occupy the home on the strength of a beneficial interest or interest in the property, he or she has a right of occupation as well as does any person under the age of 18 who occupied the home with the bankrupt at the time of the bankruptcy proceedings. ${ }^{33}$ Where the bankrupt occupies the property, he or she may be evicted only with the leave of the court on application of the trustee in terms of section 337(4) of the Insolvency Act, 1996. Where the bankrupt has such a right but does not occupy the premises, he or she may apply to court to authorise continued occupation since such a right amounts to a charge with a priority akin to an equitable interest in the property. ${ }^{34}$

Where the spouse or civil partner or former spouse or civil partner has acquired a right of occupation in the matrimonial home in terms of the Family Law Act, such a right is binding under section 336(2) of the Insolvency Act, 1996 against the trustee and forms a charge against such home. In terms of

25 The trustee must take these steps.

26 Fletcher The Law of Insolvency 222 and see ss 331-332 of the Insolvency Act, 1996.

27 Evans 2013 SA Merc LJ 119123 notes that the spouse probably has occupational rights in this instance.

28 Steyn Statutory Regulation of Forced Sale of the Home in South Africa 461 462; Steyn 2013 IIR 154; Van Heerden, Boraine and Steyn in Omar International Insolvency Law: Reforms and Challenges $227 \mathrm{ff}$; Evans 2013 SA Merc LJ $129 \mathrm{ff}$.

29 Steyn Statutory Regulation of Forced Sale of the Home in South Africa 462 with reference to $s \quad 82$ of the Civil Partnership Act, 2004 that amended the Family Law Act, 1996 to make the rules applicable to civil partnerships in the same way as these apply to marriages.

30 See ss 335A and ss 336-337 of the Insolvency Act, 1996.

31 Evans 2013 SA Merc LJ 123 and Pawlowski and Brown "Applications for Sale of the Family Home After One Year of Bankruptcy - A Creditor's Prerogative" 2015 Nottingham Insolvency and Business Law 517.

32 Ss 335A(3), 336(5) and 337(6) of the Insolvency Act, 1996.

33 Steyn Statutory Regulation of Forced Sale of the Home in South Africa 468-469 where s $337(1)(a)$ and $(b)$ are discussed.

34 Steyn Statutory Regulation of Forced Sale of the Home in South Africa 469 with reference to $s 33(2)(a)$ and $(b)$ of the Insolvency Act, 1996. 
section 336(4) the court has the discretion to make an order that it thinks just and reasonable and after considering the following:

- The interests of the creditors;

- Any contributing conduct of the spouse or civil partner or former spouse or civil partner of the bankruptcy;

- The financial resources and needs of the spouse or civil partner or former spouse or civil partner;

- The needs of any children; and

- All circumstances of the case other than the needs of the bankrupt. ${ }^{35}$

Steyn $^{36}$ mentions that the extent of protection of the family home depends largely on the courts' conception of what constitutes "exceptional circumstances" for the purposes of sections $335 \mathrm{~A}, 336$ and 337 . She ${ }^{37}$ refers to in Re Citro $^{38}$ where the judge followed a "less sympathetic approach":

"As the cases show, it is not uncommon for a wife with young children to be faced with eviction in circumstances where the realization of her beneficial interest will not produce enough to buy a comparable house in the same neighbourhood or indeed elsewhere. And, if she has to move elsewhere, there may be problems over schooling and so forth. Such circumstances, while engendering a natural sympathy in all who hear of them, cannot be described as exceptional. They are the melancholy consequences of debt and improvidence with which every civilised society has been familiar." 39

There are examples of cases where the courts adopted a more "sympathetic" approach in considering family hardship as constituting circumstances that are "exceptional". ${ }^{40}$ Various legislative amendments, more particularly the coming into force of the Human Rights Act $1998^{41}$ created an opportunity for the development of a broader interpretation of "exceptional circumstances" under the Insolvency Act, 1986 to include all instances where the family home and the rights of children are at issue. ${ }^{42}$

35 These may include the needs of the elderly or ailing, although they are not mentioned expressly - see Claughton v Charalambous [1998] BPIR 558 as referred to by Evans 2013 SA Merc LJ 126 fn 29.

36 In Steyn 2013 IIR 155.

37 Steyn 2013 IIR 156.

38 [1991] Ch 142 CA. This case was decided under the legislation applicable before the coming into force of the Insolvency Act 1986.

39 157A-D.

40 See for instance the judgments in Re Gorman [1990] 1 WLR 616; Claughton $v$ Charalambous [1999] 1 FLR 740; Re Raval [1998] BPIR 384; and Re Bremner [1999] BPIR 185; Re Bremner [1999] 1 FLR 912 referred to by Van Heerden, Boraine and Steyn in Omar International Insolvency Law: Reforms and Challenges at 236 fn 65. See also Omar "Security Over Co-Owned Property and the Creditor's Paramount Status in Recovery Proceedings" 2006 Conveyancing and Property Lawyer 157 and see Pawlowski and Brown 2015 Nottingham Insolvency and Business Law $517 \mathrm{ff}$.

41 Such as the provisions of the European Convention on Human Rights, including Article 8 of Schedule 1 of the Convention which provides that "[e]veryone has the right to respect for his private and family life, his home and his correspondence", which also applied to England and Wales as then members of the EU.

42 Richman "Using the Human Rights Act to Save the Family Home" 2000 New Law Journal 1102 1104. See also Mortgage Corporation v Shaire [2000] EWHC 452 (Ch); [2001] Ch 743 par 73 (but note this was not a bankruptcy - see Steyn 2013 IIR 156). 
Steyn ${ }^{43}$ points out that the court's remark in Barca $v$ Mears ${ }^{44}$ that the approach adopted by the majority in Re Citro ${ }^{45}$ may not comply with the European Convention on Human Rights ${ }^{46}$ and may need to be revisited is significant in this context. ${ }^{47}$

Where the value of the bankrupt's interest in a house ${ }^{48}$ is less than a prescribed minimum ${ }^{49}$ - currently GBP $1000^{50}$ - a court must dismiss an application by the trustee for an order for sale or repossession or a charging order in terms of section 313 of the Insolvency Act 1986. This principle thus prevents the sale of a bankrupt's home where the nett equity is so low that it has no benefit to creditors.

Other types of tenancies that are considered protected tenancies in terms of section 283(3A) of the Insolvency Act 1986, for example an assured tenancy or a secured tenancy in terms of the Housing Act 1985, in principle are excluded from the bankrupt's estate.

There are separate protective measures concerning an insolvent who rents a property for residential purposes regarding the protection of his or her right to tenancy. In relation to this matter and how it is addressed in English insolvency law, Spooner ${ }^{51}$ in criticising the current state of affairs, remarks that "[i]nsolvency policy makers have paid surprisingly little attention to this issue, in contrast to the frequent policy consideration of the treatment of a property-owning debtor's home."

It is worth noting the enactment of the 1996 Insolvency Act was preceded by a review committee's report on insolvency law and practice ${ }^{52}$ under the chairpersonship of the late Sir Kenneth Cork. As to the socio-economic context the report states that the family home or its residual value has frequently been the major asset of a consumer debtor and it took note of the

43 Steyn 2013 IIR 156.

44 [2004] EWHC $2170(\mathrm{Ch})$. Other relevant cases reported since the enactment of the Human Rights Act 1998 include Donohue v Ingram [2006] EWHC 282 (Ch); Nicholls v Lan [2006] EWHC 1255; 1243; Allan v Foenander [2006] EWHC 2101 (Ch); Martin-Sklan v White [2006] EWHC 3313; Turner v Avis [2007] 4 All ER 1103; [2007] EWCA Civ 748 - see Van Heerden, Boraine and Steyn in Omar International Insolvency Law: Reforms and Challenges 237 fn 68.

45 Namely, however disastrous the consequences of bankruptcy may be to family life they cannot be relied upon under s 335A(3), Insolvency Act if they simply are the usual kind of consequences of bankruptcy.

46 See fn 41 above.

47 Par 39-43 of the judgment.

48 The dwelling-house must be the sole or principal residence of the bankrupt or his or her spouse, former spouse, civil partner or former civil partner to be covered by this provision; see s 313A, Insolvency Act 1986.

49 This is in terms of s 313A, Insolvency Act 1986. See further Walters "Personal Insolvency Law After the Enterprise Act: An Appraisal" 20055 Journal of Corporate Law Studies 65; Omar 2006 Conveyancing and Property Lawyer 169.

50 Fixed in terms of Article 2, Insolvency Proceedings (Monetary Limits) (Amendment) Order 2004 (SI 2004/547).

51 Spooner "Seeking Shelter in Personal Insolvency Law: Recession, Eviction and Bankruptcy's Social Safety Net" 2017 Journal of Law and Society 374 390-391.

52 Cork Insolvency Law and Practice Report of the Review Committee (1982) and hereinafter the "Cork Report". 
shortage in accommodation as well as the cost of housing. ${ }^{53}$ Acknowledging the interests of creditors, the report also took cognisance of the considerable hardship that a sudden or premature eviction can cause to the debtor's family. The report proposed that the court should have a wide discretion to enable it to make an order that is just and equitable in a great variety of circumstances that may arise. ${ }^{54}$ In exercising its discretion the court may be expected to give consideration to the following factors, among others:

(a) the means available to the family (other than the debtor himself);

(b) how much of the debtor's income is to be contributed to the creditors, and how much is likely to be left for him and his family;

(c) the suitability of the standard of amenity provided by the present family home and the available alternatives;

(d) any offer by the debtor to move if given help (whether out of the proceeds of the sale or otherwise) in rehousing the family;

(e) the amount likely to be realised by the sale of the debtor's interest in the family home in relation to the disturbance caused;

(f) the need for the family to remain in a specific area for business or schooling reasons;

(g) any personal hardship caused to an individual creditor by a proposed postponement; and

(h) any arrangements that may have been made with a mortgagee of the premises.

The "family home" concept was defined in the Cork Report ${ }^{55}$ as a dwelling in which there is or are living the debtor and his wife, the debtor or his wife with (in either case) a dependant child or children, the debtor's wife, or the debtor and a dependant parent of the debtor or of his wife who has been living there as part of the family on the basis of a long-term arrangement. ${ }^{56}$

Steyn ${ }^{57}$ points out that the Insolvency Act, 1986 did not accept all these proposals, but it reversed the effect of the Matrimonial Homes Act, 1967 in that formerly this Act provided that the occupational rights of family members' were void against the trustee in bankruptcy.

\section{Summary}

It is clear from the discussion above that both the United States and English legal systems make provision for the protection of the homestead or at least

53 Par 1114-1121

54 Par 1122-1123.

55 Par 1124.

56 Note the criticism of the use of a term "family home" and the type of traditional relationships that it symbolises since there are single adulthood households and a range of co-habiting couples, regardless of gender, or who have not registered a civil partnership that would trigger the protective measures in bankruptcy - see Fox "Creditors and the Concept of the "Family Home": A Functional Analysis" 2006 Legal Studies 214-215; Hunter "The Nature of a Rescue Culture" 1999 Bus L 506 and Keay "Balancing Interests in Bankruptcy Law" 2001 Common L World Rev 221; Steyn Statutory Regulation of Forced Sale of the Home in South Africa $490 \mathrm{fn} 419$ and 420.

57 Steyn Statutory Regulation of Forced Sale of the Home in South Africa 461. 
for a housing interest in insolvency. The United States system follows the approach to allow at least for a level of exemption that may include a portion of the equity of the primary residence of the insolvent, whereas the English system in principle allows for a kind of protection that permits the insolvent and or his spouse and other related family members to remain in possession of the family home at least for a 12 month period. The way in which the protection is granted in England may differ fundamentally but in essence the notion of family home protection is not a new concept. An insolvent in the United States either in some states keeps his or her house (the primary residence) or in others at least gets a portion of the equity, if any, that may assist them to acquire accommodation. In the English system the protection in principle is meant to be temporary but the insolvent also has the opportunity during this period to find other accommodation or to make a debt arrangement with the mortgagee should the family home be mortgaged. Under certain circumstances, for instance, where the value of the property is below a certain threshold, the bankrupt will be able to keep it.

\begin{tabular}{|c|c|c|}
\hline & SOUTH & AFRICA \\
\hline INDI & EXECUTION & PROCEDURE \\
\hline $\begin{array}{l}\text { RELATING TC } \\
\text { HOMESTEAD }^{58}\end{array}$ & ATTACHMENT & OF \\
\hline
\end{tabular}

Broadly speaking, the process of individual execution at the behest of a judgment creditor entails the attachment and judicial sale in execution by the sheriff of the property of the judgment debtor in order to realise the value and to utilise the proceeds to satisfy a judgment sounding in money in circumstances where the estate of the insolvent has not been sequestrated. $^{59}$

This procedure amounts to an individual debt collecting or debtenforcement and execution procedure, since the process must be utilised by every individual creditor in relation to the debt owing to him or her. Where the debtor is insolvent creditors probably revert to a collective procedure by applying for the sequestration of the estate of the debtor in the case of a

58 See Theophilopolous, Van Heerden and Boraine Fundamental Principles of Civil Procedure 3ed (2015) $404 \mathrm{ff}$ where this aspect is discussed and on which this section is largely based (hereinafter "Theophilopoulos, Van Heerden and Boraine"). See further Brits Mortgage Foreclosure Under the Constitution: Property, Housing and the National Credit Act (doctoral thesis, US) 2012; Brits 2014 TSAR 288; Brits "Protection for Homes During Mortgage Enforcement: Human Rights Approaches in South African and English Law" 2015 SALJ 566; Brits "Executing a Judgment Debt Against Immovable Property Occupied as a Family Home in Customary Law: Nedbank Limited v Molebaloa" 2019 SA Merc LJ 348; Brits Real Security (2016) 68-100; Van Loggerenberg Jones and Buckle: The Civil Practice of the Magistrates' Courts in South Africa 10ed (2019 update) regarding the commentary on s 66 of the Magistrates Courts Act and magistrates' court rules 5 and 43A; Van Loggerenberg Erasmus: Superior Court Practice (2019 update) D1-631-D1-632; Steyn Statutory Regulation of Forced Sale of the Home in South Africa ch 5; Steyn "Executing Against a Mortgaged Property - A Transformed, Yet Evolving, Landscape: Firstrand Bank Ltd V Mdletye (KZD) and Firstrand Bank T/A First National Bank v Zwane (GJ)" 2019 SALJ 446.

59 An attachment in execution creates a judicial mortgage (pignus judiciale) in favour of the judgment creditor. 
natural person as provided by the Insolvency Act. ${ }^{60}$ From commencement of sequestration the insolvent estate's property vests in the trustee as from his or her date of appointment. ${ }^{61}$ Commencement of sequestration causes a concursus creditorum and no creditor as from commencement is able to continue with the individual collecting and execution process. In Walker $v$ Syfret ${ }^{62}$ the court explained the key concept of concursus creditorum as follows:

"The sequestration order crystallises the insolvent's position; the hand of the law is laid upon the estate, and at once the rights of the general body of creditors have to be taken into consideration. No transaction can thereafter be entered into with regard to estate matters by a single creditor to the prejudice of the general body. The claim of each creditor must be dealt with as it existed at the issue of the order."

In case of individual attachment of immovable property, and for the purposes of this discussion in particular the attachment of the judgment debtor's home, this situation has become a subject of great importance in the context of the individual debt collecting and execution procedures. ${ }^{63}$ The genesis for this development is to be found in section 26(3) of the Bill of Rights contained in the Constitution, which provides that "no one may be evicted from their home without an order of court made after consideration of all the relevant circumstances". The right to attachment and execution of a judgment debt by a creditor therefore was qualified by the Constitutional Court in the judgment of Jaftha $v$ Schoeman; Van Rooyen $v$ Stoltz ${ }^{64}$ in which the court held that the Magistrates' Court attachment process, specifically as set out in section 66 of the Magistrates' Courts Act as it then read, was unconstitutional in so far as it did not provide for judicial supervision over the attachment of immovable property.

In the Jaftha case the state-subsidised homes that were not subject to mortgage bonds of two indigent persons became the objects of execution for judgment debts following default judgment. The Constitutional Court found that any legal process or measure which deprives persons of their preexisting access to adequate housing is unconstitutional because it limits the right to housing as defined in section 26(1) of the Constitution. To overcome the problem of execution without judicial oversight, the Constitutional Court proposed a remedy by reading into section 66 judicial oversight of the execution process - specifically that magistrates must consider carefully the facts of each case in order to determine before a writ of attachment in

\footnotetext{
Act 24 of 1936 (the Insolvency Act).

$\mathrm{S} 20$ of the Insolvency Act.

621911 AD 141 166. See also Corporate of Empire Gardens v Sithole 2017 (4) SA 161 (SCA) par 9.

63 See in general, Brits Statutory Regulation of Forced Sale of the Home in South Africa (doctoral thesis, US) 2012 and Steyn Statutory Regulation of Forced Sale of the Home in South Africa. This section is concerned with execution as such, but the developments regarding evictions are relevant for a comprehensive understanding of the broader issue, namely the arbitrary evictions from their homes - see in general Bilchitz and Mackintosh "Pie in the Sky: Where is the Constitutional Framework in High Court Proceedings? Marlboro Crisis Committee v City of Johannesburg" 2014 SALJ 521. Also see other publications referred to in fn 58 above.

642005 (1) BCLR 78 (CC).
} 
respect of immovable property is issued in terms of section 66 whether execution will be reasonable and justifiable in the circumstances. ${ }^{65}$

The court $^{66}$ listed certain factors that may be considered when adjudicating such a matter. These factors, as augmented by subsequent judgments, ${ }^{67}$ without being a complete list, are relevant when considering such requests and they are summarised as follows: ${ }^{68}$

- Whether the rules of court have been complied with;

- Whether there are other reasonable ways in which the judgment debt can be paid;

- The circumstances under which the debt had been incurred;

- $\quad$ Any attempts made by the debtor to pay off the debt;

- The financial situation of the parties;

- The amount of the debt;

- Whether the debtor was employed or had a source of income to pay off the debt;

- The availability of alternatives which might allow for the recovery of debt but did not require the sale in execution of the debtor's home, for example, paying off the debt in instalments;

- Whether there is any disproportionality between execution and other possible means to exact payment of the judgment debt; ${ }^{69}$

- Any other factor relevant to the particular facts of the case before the court.

It must be noted in respect of a plaintiff-creditor's claim directed at executing residential property of the defendant-debtor that section 5(1) of the Magistrates' Court Act has been amended and now requires that the

65 The Jaftha judgment caused judicial oversight to become the norm in order to obtain a proper attachment and execution order against the house of a debtor, as well as did subsequent amendments to s 5 and 66 and to rule 43A of the Magistrates' Court Act 32 of 1944 and the Magistrates' Court Rules (MCR). See for background Van Heerden and Boraine "Reading Procedure and Substance into the Basic Right to Security of Tenure" 2006 De Jure 319. In SANI v FirstRand Bank Ltd 2012 (4) SA 370 (WCC) par 3 and 50, the court held that an execution that was finalised prior to $s 6$ being declared invalid first must be set aside before the sale in execution subsequent to transfer of such property can be undone.

66 Jaftha judgment $162 \mathrm{~A}-\mathrm{F}$.

67 After an initial judgment in Standard Bank of South Africa Ltd v Saunderson 2006 (2) SA 264 (SCA) par 19-21 where the court regarded it as unlikely that a s 26 defence could ever cause a foreclosure action to be denied, subsequent cases indeed found such factors, especially where the amount in arrears was disproportionately small in comparison to the impact of losing one's home - see ABSA Bank Ltd v Ntsane 2007 (3) SA 554 (T) and Firstrand Bank Ltd v Maleke 2010 (1) SA 143 (GSJ) as referred to and discussed by Brits Real Security Law (2016) 72-73 and see further cases referred to at $73 \mathrm{fn} 334$. See also Brits 2015 SALJ 566; Brits 2018 SA Merc LJ 348; Steyn 2018 SALJ 566; and Muller, Brits, Pienaar and Boggenpoel Silberberg and Schoeman's: The Law of Property par 16.3.6 for a further discussion of relevant cases etc.

68 Van Loggerenberg Erasmus: Superior Court Practice (2019 update) D1-631-D1-632 and Jaftha 163 A-B. See further Van Loggerenberg Erasmus: Superior Court Practice D1-632 ff regarding various practices that emerged in the different division of the High Court prior to the further amendment of HCR 46 in 2017.

69 See for instance ABSA Bank Ltd v Ntsane supra; and Gundwana v Steko Development CC 2011 (3) SA 608 (CC). 
summons contain a notice drawing the defendant's attention to section 26(1) of the Constitution of 1996 regarding the basic right of access to housing. The defendant is then bound to place information before the court to support such a claim when he or she pleads that an order for attachment will infringe this basic right. Magistrates' Court Rule $5^{70}$ and section 66 of the Magistrates Court Act have been amended to align to the Jaftha judgment by requiring judicial oversight before the primary residence becomes subject to an attachment order. A new Magistrates' Court rule, MCR 43A, requires a court to consider all relevant factors, before execution is granted against immovable property which is the primary residence of the judgment debtor.

In subsequent cases the effect of the Jaftha decision was considered in the realm of High Court procedures regarding the execution of residences that were mortgaged. It seems as though the courts were more reluctant to protect the execution of mortgaged property than is the case of property not subject to a mortgage bond as in the Jaftha case; there seems to be a general view that a person who can afford a mortgage bond probably is more affluent and may have greater means to find alternative accommodation than the vulnerable type of debtor as in the Jaftha case. In most subsequent cases the creditor-plaintiff obtained a default judgment in terms of High Court Rule ${ }^{71} 31(5)$ and obtained an order whereby such residences were declared especially executable in terms of the former HCR 46. These two rules were thus used together to obtain a judgment by default and to declare immovable property especially executable.

After a number of further judgments ${ }^{72}$ the Constitutional Court ruled in Gundwana $v$ Steko Development $C^{73}$ unconstitutional the former process in terms of which the registrar of the High Court granted default judgment and declared immovable property subject to a mortgage bond (i.e. the home of the defendant-debtor) especially executable. This judgment led to the first amendments of HCR 31 and the proviso to sub-rule 31(5)(b) read with HCR 46(1)(a)(ii) which require the registrar in applications for default judgment concerning the primary residence of the debtor to refer the matter to the court before it can be declared especially executable. ${ }^{74}$

The addition of HCR 46A again amended the relevant rules of the High Court in 2017to deal more comprehensively with execution against residential immovable property. In essence rule 46A applies where any residential immovable property of the debtor is to be executed against. ${ }^{75}$ The

\footnotetext{
Hereinafter MCR.

Hereinafter HCR.

72 With regard to HCR 31(5) the Supreme Court of Appeal previously held that the registrar of the High Court may continue to grant default judgment declaring especially hypothecated immovable property executable when such judgment is applied for on the basis of a debt flowing from the mortgage bond over the property. Although a full bench of the then WLD ruled that the Jaftha case would affect HCR 46(1) and that judicial supervision of this procedure had to be read into this rule, the Supreme Court of Appeal in Standard Bank of South Africa Ltd $v$ Saunderson supra par 19 found it unnecessary so to do.

73 Supra par 41, 49-50 and 53.

74 See Muller et al Silberberg and Schoeman's: The Law of Property $24 \mathrm{fn} 219$ for case references where relevant circumstances were applied following these amendments to HCR 46(1)(a)(ii).

75 See HCR $46 A(1)$. This rule is similar to MCR 43A.
} 
court hearing the matter, then determines if the immovable property is the primary residence of the judgment debtor and if so, considers alternative means available to the judgment debtor to satisfy the debt other than execution against the primary residence. HCR $46 \mathrm{~A}(2)(\mathrm{b})$ makes it clear that execution against the primary residence may not be authorised by the court unless the court having considered all the relevant factors considers the execution warranted. The registrar of the court also may not issue a writ of execution against the residential property of the judgment debtor unless a court ordered execution. ${ }^{76}$ The application to court must include full information concerning the market value of the property and debts in relation to it, such as the balances still due and owing to a mortgagee (if any) and other charges against it, such as rates and taxes or other levies. ${ }^{17}$ The judgment debtor as a matter of course has an opportunity to oppose the application or otherwise may make submissions that are relevant to the making of an appropriate order by the court. ${ }^{78}$ The court hearing the matter has wide powers in granting an order, ${ }^{79}$ which may include the conditions of sale (perhaps this includes that the judgment debtor may remain in occupancy for some time after the sale), setting a reserve price for the property to be ultimately sold in execution ${ }^{80}$ and order execution or refuse or any other appropriate order.

Van Loggerenberg ${ }^{81}$ points out that apart from the prescribed information relating to the market value etc. of the primary residence the court may call for other documents, which it considers necessary and this information constitutes "relevant information" in terms of HCR 46A(5), but the author indicates that the following relevant factors can be gleaned from the new HCR 46A, namely:

(a) Alternative means by the judgment debtor to satisfy the debt other than execution in terms of HCR 46A(9)(ii);

(b) Person occupying the primary residence and their circumstances in terms of HCR $46 \mathrm{~A}(9)(\mathrm{b})(\mathrm{vi})$;

(c) Effect of the inclusion of appropriate conditions in the conditions of a possible sale in execution of the judgment in terms of HCR $46 \mathrm{~A}(8)(\mathrm{a})$; and

(d) Any other factor the court may deem necessary for the protection of both the execution creditor and the judgment debtor in terms HCR $46 \mathrm{~A}(9)(\mathrm{b})(\mathrm{ix}){ }^{82}$

HCR 46A(2)(c).

HCR 46A(5).

HCR 46A(6).

HCR $46 \mathrm{~A}(8)$ and (9).

80 It is to be noted that properties were sold far below market value in execution sales where the property was sold without reserve. In an attempt to address this aspect the new HCR 46A makes provision to enable a court to set a reserve price. Debtors clearly were prejudiced if the property was sold below market value since they still are saddled with the balance of the debt.

81 Erasmus: Superior Court Practice D1-632-1.

82 It is clear that the court must consider the position of the creditor and the debtor - see for instance at 1611 where the court in the Jaftha judgment referred to the principle of pacta sunt servanda as well in the ambit of considerations to be considered by the court. 
The learned author submits that the relevant circumstances developed by earlier cases referred to above and before HCR 46 was amended, may also be relevant to the extent that they are not included already in the relevant factors listed in HCR 46A. ${ }^{83}$ He makes the important point that such factors are not exhaustive and every case must be considered in terms of its own facts. ${ }^{84}$

As stated before, South African courts initially were somewhat reluctant to give debtors' resident in mortgaged homes the same sort of blanket protection as given to the indigent debtors with state-subsidised houses in Jaftha. Still, in ABSA Bank Ltd $v$ Ntsane ${ }^{85}$ as mentioned before, the court was prepared to protect a mortgagor, though notably, the arrear amount owing to the mortgagee was very little. It is now clear that a court has to consider whether execution of a debtor's home, regardless of whether or not it is subject to a mortgage bond, infringes his or her right to housing or other basic rights enshrined in the Constitution. The reasons for this necessity are to be found in the Gundwana judgment in which the Constitutional Court stated that the Jaftha factors do not constitute a complete list, and in the amendment of High Court Rule 46 that now provides that when the property sought to be attached is the primary residence of the judgment debtor no writ of attachment shall be issued unless the court, having considered all the relevant circumstances, orders execution against the property.

In passing, it must be noted that in case of bonded property the rights of the mortgagee-creditor remain important and must be weighed against the constitutional right of the debtor not to be deprived of his or her home without due process being followed by a court of law. Pertinent to such an enquiry will be if an arrangement can be made regarding the repayment of the mortgage bond. Apart from the aforementioned safety valves built into individual execution procedures following the developments subsequent to the Jaftha judgment, a debtor may avail him- or herself of other measures such as the statutory debt relief measures provided in the National Credit Act that allow a debt rearrangement with the creditor. ${ }^{86}$ Steyn $^{87}$ states

33 Van Loggerenberg Erasmus: Superior Court Practice D1-632-1.

84 Ibid.

85 Supra and cases and other references in fn 67 above. Nedbank Ltd $v$ Fraser and four other cases 2011 (4) SA 363 (GSJ).

86 See s 86 of the National Credit Act and instances where the courts refused applications for voluntary surrender under circumstances where debt review in terms of the National Credit Act could provide solutions - perhaps more advantageous to the creditor(s) than sequestration, see Ex Parte Ford 2009 (3) SA 376 (WCC) as discussed by Van Heerden and Boraine "The Interaction Between the Debt Relief Measures in the National Credit Act 34 of 2005 and Aspects of Insolvency Law" 2009 PELJ 161. In a recent but peculiar application for voluntary surrender, namely Jordaan $v$ Jordaan [2020] JOL 46613 (FS) the court also refused an application for voluntary surrender while considering the granting of a sequestration order and its effect on the house of a debtor co-owned by him and his exwife. The wife opposed the voluntary surrender application while being under debt review herself. The court however raised issues concerning the rights of the occupants of the house in view of $s 26$ of the Constitution and the fact that the sequestration will cause the loss of the house - par 8-11. With reference to the Ford judgment the court also considered the fact that debt relief may be a solution better than sequestration, - par 12 .

87 Steyn 2013 IIR 165 where the author refers to some support for this approach in a number of listed judgments. 
"[c]onsumer debt relief measures may offer an alternative to sequestration and hold the potential to avert the forced sale of a debtor's home in circumstances where the debtor has a regular income that will allow him to service his debt over a longer period."

At least this is a statutory measure that could assist a debtor to keep the house but of course it will depend on the financial position of the debtor if such a rearrangement will be feasible or not in the circumstances. The essence is that the debtor is provided with a process that may enable him or her to keep the house, while rescheduling the debt. ${ }^{88}$ Clearly, where this is not possible the issue of the debtor and his or her dependants being rendered homeless becomes very important in order to take into consideration his or her continued occupation of the house.

In a recent case, Jordaan $v$ Jordaan ${ }^{89}$ the court alluded to the effect that a sequestration order may have on the rights of occupancy relating to a property used as the primary residence by the ex-wife of the debtorapplicant and their children in an application for voluntary surrender for his estate by the ex-husband. The property was their family home and apparently registered in their names in half undivided shares each. Yet, as part of the divorce settlement the debtor (ex-husband) granted his former wife and the respondent in this application, his undivided share in the property as well. (At the time of the application the ex-wife's share was not yet registered in her name.) The property was also subject to a mortgage bond, so the applicant had secured debt in the form of the mortgage bond as well as having concurrent creditors. The house was the main asset to be used to settle his debts by means sequestration, but the ex-wife occupied it, who was herself under debt review, and their children. The ex-wife opposed the application for voluntary surrender on the basis that the sequestration of the insolvent estate of the debtor-applicant may cause her and the children to be evicted from the house. She indicated that she had paid the mortgage bond instalments and is trying to continue to do so while under debt review. This fact was an important consideration for the court in not granting the sequestration order. $^{90}$ In its judgment the court discussed the impact of section 26 of the Constitution etcetera but it must be noted that the debtorapplicant was not occupying the property himself. The court also considered the fact that the respondent acquired a personal right in the property (to claim transfer of the $50 \%$ undivided share), and the court held in paragraph 10 that this right "precedes any right that the applicant's creditors may have in the property". This case opens up further discussions regarding the protection of the homestead or primary residence at the time of hearing the sequestration application as such, but this is not the main focus of this article - although it remains an important aspect in the broad consideration of the protection of the primary residence of a vulnerable debtor and / or his dependants.

To summarise, as a result of the developments in case law the court rules have been amended as mentioned above, to deal with attachment and

88 See references to the Ex parte Ford supra and Jordaan $v$ Jordaan supra judgments in fn 86 above.

89 Supra.

90 Par 8-10. 
execution against the primary residence of a debtor. The line of decisions clearly influenced the development of the individual execution process relating to residential property used as the primary residence by the debtor. It is submitted that the individual execution procedures as provided for in legislation and the rules of court must be read with the Constitutional Court's approaches in mind.

South African case law and legislative developments thus show a progression towards the protection of a debtor's section 26 Constitutional rights against arbitrary deprivation - "arbitrary" in it being effected without a court's exercising its discretion to declare the home of a judgment debtor used as his or her primary residence especially executable. Most importantly, case law recognises that there may be special circumstances in which a debtor's right of access to adequate housing and security of tenure should be upheld even when his or her creditor has a valid claim and has obtained judgment against the debtor. Also, it must be noted that the current protective measures in the rules of the high and magistrates' courts following a line of judgments relate to the attachment and execution against the primary residence being immovable property of the judgment debtor. There is no direct provision relating to movable property, such as a caravan, used as a dwelling or shelter by the debtor being subject to the same judicial oversight and it is questionable if the same kind of development will follow in this respect. Also, it is a general rule that movable property first must be executed upon for settlement of a judgment debt before immovable property is attached. ${ }^{9}$

Also, it must be noted that the ideal situation is to grant the debtor an opportunity to make alternative repayment plans with the judgment creditor in order to keep the house (primary residence) but at the same time a debtor who clearly cannot repay any part of a debt and who is rendered homeless by attachment and an execution sale of the home may convince a court to allow continued occupation. The duration of the last mentioned continuing stay is not spelled out and it may be open to the creditor to seek attachment and execution at a later stage for instance should the financial position of the debtor improve.

Although the sentiments and factors to be considered as discussed above should be relevant after sequestration in relation to the family home or primary residence of the insolvent, the cases referred to in this section and the legislative amendments did not affect insolvency procedures in terms of the Insolvency Act as such.

\section{SOME RELEVANT SOUTH AFRICAN INSOLVENCY LAW PRINCIPLES}

As far as South African insolvency law is concerned it must be understood that the insolvency law does not provide for any type of protection to the insolvent debtor and his or her dependants in relation to the family home or primary residence either by way of dispensations such as those in the USA

91 See HCR 45 and 46. 
or in England or such as the progressive measures in our debt execution law. ${ }^{92}$

Nevertheless, it is important to have a broad understanding of the structure of insolvency law in order to see the extent to which there may be room for protecting the interests of the insolvent and to prevent the insolvent and/or the dependants rendered homeless. ${ }^{93}$ It must be noted that insolvency, like individual execution procedures as discussed above in paragraph 3 , causes a forced sale but of all the realisable assets of the insolvent with the view of distributing the available proceeds to the creditors in accordance with the distribution rules of the Insolvency Act since the sequestration order brings a concursus creditorum about. In this respect the developments concerning the primary residence protection in individual debt execution may be relevant. If the primary residence cannot be saved before a sequestration order is granted, the question is to what extent the continued occupation of the insolvent and his or her dependants can be maintained at least until they are in a position to find alternative accommodation. As mentioned in paragraph 1 before, the PIE Act may be applicable depending on the facts of the case - and the aim of this article is to consider various aspects of this option. In order to gain a better understanding of various relevant aspects from an insolvency point of view, a basic overview of the structure of insolvency law is provided.

Formal insolvency is nevertheless initiated by a successful application for voluntary surrender by the debtor or by means of a compulsory sequestration application by a creditor. In both instances the applicant must satisfy the court that the statutory procedural and substantive requirements for the respective applications have been met before a sequestration order will be granted. ${ }^{95}$ In both instances the granting of the sequestration order is at the discretion of the court in spite of proof that in principle the requirements have been met. ${ }^{96}$

It must be noted that the debtor may apply for a sequestration order by means of an application for voluntary surrender. Among other requirements, the debtor-applicant must prove to the court that his or her estate factually is insolvent, that there will be sufficient free residue to meet the costs of sequestration and that sequestration would be to the advantage of creditors. $^{97}$ The courts have discretion to grant the order or not and, in particular, by considering the advantage for a creditor's requirement should decide if sequestration is the best option under the circumstances. Where there is a better alternative to settle the debt, for instance by way of debt

92 For a discussion on the socio-economic and welfare aims of consumer insolvency see in general Spooner 2017 Journal of Law and Society $374 \mathrm{ff}$.

93 See Steyn Statutory Regulation of Forced Sale of the Home in South Africa ch 6 for a more comprehensive discussion of the insolvency related aspects.

94 For a comprehensive discussion of South African insolvency law, see in general Kunst, Boraine and Burdette Meskin the Law of Insolvency (2019 update) (loose leaf) and Bertelsmann, Calitz, Evans, Harris, Kelly-Louw, Loubser, De la Rey, Roestoff, Smith Stander and Steyn Mars: The Law of Insolvency 10ed (2019).

95 See ss 4-6 of the Insolvency Act regarding the requirements for voluntary surrender and ss 7-12 for the requirements for compulsory sequestration.

96 See ss 6(1) and 12(1) of the Insolvency Act respectively.

97 Ss 3-6 of the Insolvency Act. 
review in terms of the National Credit Act, the court may refuse the application. In such instances the courts have considered such an option ${ }^{98}$ and in a recent case considered the effect of the sequestration of the debtorapplicant's estate on the section 26 constitutional housing rights of his exwife and children, where he and his ex-wife held the property in a half-share undivided share each.

In a case of a compulsory sequestration application brought by a creditor or creditors against the debtor it may well be asked if in exercising its discretion the court should consider a plea by the respondent that the sequestration order may cause the loss of his or her primary residence that will leave him or her homeless ${ }^{99}$ In brief, the requirements to be covered in the application in terms of section 10 of the Insolvency Act and to be proved by the applicant-creditor are that:

(a) the applicant qualifies as a creditor who has locus standi to bring such an application; ${ }^{100}$

(b) the debtor is factually insolvent or committed an act of insolvency in terms of section 8 of the Insolvency Act;

(c) facts exist which establish that there would be reason to believe that sequestration would be to the advantage of the creditors.

Where these requirements have been met nevertheless there may be special circumstances such as abuse of process which convince the court not to grant the order. ${ }^{101}$ Currently, there is no direct and clear authority that a court should consider the fact that sequestration following a compulsory sequestration application renders the insolvent homeless, and such a plea by the respondent-debtor will be weighed against the entrenched advantage for creditors-principle that is a hallmark of our rather pro-creditor insolvency system. ${ }^{102}$ Yet, as a matter of principle, the question may be posed if the same kind of principles provided in the rules of the court following the judgments in Jaftha and subsequent cases should not be considered in case of especially compulsory sequestration applications as well. What definitely is clear is that in view of the court's discretion when hearing an application, it should consider if there are better alternatives than sequestration to deal with the debt situation. In this regard the possibility should be considered for instance of debt rearrangement in terms of the National Credit Act. If the

98 See for instance Ex Parte Ford supra and Jordaan $v$ Jordaan supra discussed under heading 4 and referred to in fn 86 above.

99 See in general the references to commentators in fn 2 and 58 above.

100 A creditor who has a liquidated claim of at least R100 or where a number of creditors apply jointly where the total of their claims in aggregate is not less than R200 alone may bring such an application to court - see s 9(1) of the Insolvency Act.

101 See also Kleinfontein Boerebelange Koöperatief Bpk v Zeevaart [2014] JOL 32455 (GP) par 29-33; Millward v Glaser 1950 (3) SA 547 (W) 553-554; Chenille Industries v Vorster 1953 (2) SA 691 (O) 700; Realizations Ltd v Ager 1961 (4) SA 10 (D) 11-12; Cyril Smiedt (Pty) Ltd $v$ Lourens 1966 (1) SA 150 (O) 155-156; Benade v Boedel Alexander 1967 (1) SA 648 (O) 655-656.

102 Steyn Statutory Regulation of Forced Sale of the Home in South Africa 339 with further references to discussions on this aspect. It must be noted that our system is largely a procreditor system and the interests of the creditors remain of paramount importance due to the statutory prescribed advantage of creditors-principle - See Smith Insolvency Law 3ed (1988) $1-4$. 
debtor raises this or another debt arrangement proposal or option as a possible solution to deal with the debt situation, the court should take it into consideration. However, it is stressed that the court will have to consider this arrangement from the vantage point of the advantage of the creditor's requirement, but a carefully crafted argument based on section 26 of the Constitution supported by relevant facts may convince the court not to grant the sequestration order. As discussed above, ${ }^{103}$ these considerations in fact were considered in a very recent judgment where the court considered that the order probably would cause the eviction of an ex-wife and their children from the house in which both parties held a $50 \%$ undivided share. It must be noted that this case presents a very peculiar set of facts and the debtor did not occupy the house, but the judgment has opened possibilities to raise the matter of eviction in opposing compulsory sequestrations as well. Clearly, where there is no reasonable prospect of an advantage to creditors an application for sequestration, either by way of voluntary surrender or compulsory sequestration should not succeed.

When a sequestration order succeeds, a concursus creditorum ensues, the insolvent is divested of his or her estate, and it vests in the Master of the High Court until a trustee is appointed..$^{104}$ On the appointment of the trustee, the machinery of the insolvency law is in completely set into motion and the insolvent estate property or assets, bar certain protected and exempt or excluded assets, then vest in the trustee. ${ }^{105}$ However, the insolvent retains a reversionary interest in the estate. ${ }^{106}$ After his rehabilitation the insolvent, where the debtor was not actually insolvent or in cases where the assets increased in value, is entitled to any residue of the estate after all debts have been paid. ${ }^{107}$ In terms of a composition with creditors, it is possible for the insolvent to regain control of a part or the whole of the estate from the date determined in the composition. ${ }^{108}$ Where a sequestration order has been set aside, the insolvent also regains control of the estate. ${ }^{109}$

103 See fn 86 and heading 4 above.

104 It seems that it has been accepted that for all purposes the trustee becomes the owner of the estate assets - see De Villiers NO v Delta Cables (Pty) Ltd 1992 (1) SA 9(A) and Harksen $v$ Lane NO 1998 (1) SA 300 (CC) but from a theoretical point of view it is not clear if the vesting of the estate property in the trustee as envisaged by $s 20$ of the Insolvency Act causes the trustee to become the real "owner" in the common law sense of the word of such property. The trustee nevertheless for practical purposes is deemed to be the owner and he or she acquires statutory powers to deal with such property including the right to realise it to the benefit of the creditors but on their instruction or that of the Master and within the confines of the Insolvency Act. For a comprehensive discussion of this issue, see Evans $A$ Critical Analysis of Problem Areas in Respect of Assets of Insolvent Estates of Individuals (doctoral thesis, University of Pretoria) 2008 210-217. See also Botha NO v Kies supra par 8; Starbuck NO v Halim unreported case no 12535 of 2015 (GP) par 7 and 8.

105 Smith Insolvency Law 3 and see s 20(1)(a) of the Insolvency Act 24 of 1936. Further, see De Villiers NO v Delta Cables (Pty) Ltd supra 15G-H; Harksen v Lane NO supra par 35; Fourie NO v Edkins 2013 (6) SA 576 (SCA) and Evans and Steyn "Property in Insolvent Estates Edkins v Registrar of Deeds, Fourie v Edkins and Motala v Moller" in 2014 PELJ 2746 for a discussion of these aspects.

$106 \mathrm{~S} 20(1)(a)$ of the Insolvency Act.

107 Ss 116, 124(3) and (5) and 129(2) of the Insolvency Act.

108 S 120(2) and see ss 123(1) and (2) of the Insolvency Act.

109 Mahommed $v$ Lockhat Bros \& Co Ltd 944 AD 241. 
The insolvent estate comprises the "property" of the insolvent except for the protected (excluded or exempt) categories. In terms of the definitions of key terms contained in section 2 of the Insolvency Act, "property" includes movable or immovable property wherever situated within the Republic and includes contingent interests in property other than the contingent interests of a fidei commissary heir or legatee. In principle, all property falling under this definition vests in the trustee except assets specifically excluded. The family home or house of the insolvent is not so excluded or otherwise protected in terms of insolvency law.

It is important to note that the assets of the insolvent's spouse as defined in section 21(13) of the Insolvency Act also may vest with the trustee. ${ }^{110}$ Thus, this section is relevant to this discussion since it provides that the additional effect of the sequestration of the separate (and solvent) estate of one of the two spouses shall be to vest the assets of the solvent spouse in the Master and upon his or her appointment in the trustee who may deal with it as if it was property of the sequestrated estate. ${ }^{111}$ It may be that in this instance, the family home is registered in the name of the solvent spouse. The solvent spouse may claim a release of assets to which he or she has a valid title but if such claim is unsuccessful or if it is not claimed, such assets will be sold as part of the estate as if they are assets of the insolvent spouse although subject to the rights of creditors of the solvent spouse (where the parties are married in community of property section 21 will not apply and the joint estate will be sequestrated since both will become insolvents, in which case the family home in any event forms part of the joint estate and section).

Although the family home or primary residence of the insolvent is not excluded or exempt from the insolvent estate property, certain property is excluded from the estate such as the income the insolvent earned after sequestration (if any) and to the amount required for his or her support and that of the insolvent's dependants. ${ }^{112}$ If this is the case, it will be an important factor to determine if the insolvent can afford alternative accommodation. Section 82(6) of the Insolvency Act excludes the wearing apparel and bedding of the insolvent and the whole or such part of his or her household furniture, tools, and other essential means of subsistence as the creditors, or if no creditors have proven a claim, the Master may determine. The trustee before the second meeting of creditors and with the consent of the Master may allow the insolvent a moderate sum of money or such moderate quantity of goods out of the estate as appear to be necessary for the support

110 S 21(13) the term "spouse" includes not only a wife or husband in the legal sense, but also a wife or husband by virtue of any marriage according to any law or custom, and also parties living together as husband or wife although not legally married.

111 This section survived a constitutional attack in the judgment of Harksen $v$ Lane NO supra but the view persists that this provison is unconstitutional and should be removed from our insolvency law - see Evans A Critical Analysis of Problem Areas in Respect of Assets of Insolvent Estates of Individuals 207 and 361. Although various points of view exist regarding the question if such property vested in the same way in the trustee as those of the insolvent spouse, it is assumed for purposes of this discussion that the legal status will be similar except where such property is successfully reclaimed by the solvent spouse. See Evans A Critical Analysis of Problem Areas in Respect of Assets of Insolvent Estates of Individuals $207 \mathrm{ff}$ for a comprehensive discussion of this aspect.

112 S 23(3) and (9). 
of the insolvent and his or her dependants. Any such support must be reported to the creditors at the second meeting of creditors and they may direct the trustee to provide further support if any, in terms of section $81(1)(e)$ read with section $81(3)(a)$. Clearly, it depends on the availability of money and relevant goods but in practice will not necessarily meet the needs of the insolvent and his or her dependants regarding housing etcetera.

In relation to movable property the sheriff makes an inventory and attaches such property after the commencement of sequestration. ${ }^{113}$ Such movable assets must be attached and depending on the nature of the assets be kept in a suitable place or a suitable person must be appointed to hold them in custody. The same principle does not apply to immovable assets but the Master and the trustee have duties to ensure its preservation. What is clear is that all estate property, movable and immovable, as defined in section 2 of the Insolvency Act vests in the Master until the appointment of the trustee from which moment it vests in him or her in terms of section 20 of the Insolvency Act. ${ }^{114}$

The trustee has a statutory power in terms of section 69 of the Insolvency Act to take charge of the movable property of the estate and claim estate property from the insolvent or any other person(s) in possession by applying for a search warrant with a view to finding and taking possession of such assets. The trustee thus effectively is empowered to apply for a search and seize warrant.

Apart from the estate property or assets, including the family home, vesting in the trustee as from his or her appointment in terms of section 20 of the Insolvency Act, the trustee has a statutory duty to realise such property including the family home and to the benefit of the creditors. ${ }^{115}$

The Insolvency Act contains a number of provisions dealing with the sale of insolvent estate property. The general rule is that the trustee should realise the property as directed by the creditors at the second meeting of creditors but there are a number of other ways to sell the property as well. ${ }^{116}$ Section 82 of the Insolvency Act provides that, subject to the provisions of sections 83 (realisation of securities for claims) and 90 (rights of the Land Bank) the trustee as soon as he or she is authorised to do so at the second meeting shall sell all the property of the estate in such manner and upon such conditions as the creditors may direct.

Where a provisional trustee has been appointed he or she may not, without the authority of the Master sell the property of the estate. ${ }^{17}$ The Master at any time before the second meeting of creditors may authorise the

\footnotetext{
S 19 of the Insolvency Act.

114 See further par 7 in the forthcoming Part 2.

115 Gluckman v Wylde 1933 EDL 322.

116 See s 82 of the Insolvency Act. In Mookrey v Smith NO 1989 (2) SA 707 (C) 711 the court found that a consequence of this section is that the trustee requires the authority of either the Master or of the creditors to sell the property of the insolvent estate and termed the trustee a statutory agent.

117 S 18(3) of the Insolvency Act.
} 
sale of property on such conditions and in such manner as the Master may direct. ${ }^{118}$

After his appointment the (final) trustee reports to the creditors at the second meeting of creditors concerning the state of affairs in the insolvent estate and proposes a liquidation plan to them with a view to obtaining their direction. Creditors may prescribe the manner of and the conditions for the sale of property after the second meeting ${ }^{119}$ and must give their consent if the trustee takes over a security at the value placed thereon by the creditor when proving his or her claim. ${ }^{120}$ In practice creditors usually accept the proposals of the trustee in this regard.

If the creditors at the second meeting have not given any instructions the trustee shall sell the property by public auction or public tender after notice in the Gazette ${ }^{121}$ and after such other notices and upon such conditions as the Master may direct. The property is usually sold by means of a public auction since the tender process is deemed to be too cumbersome. It must be noted that the Insolvency Act does not refer to the sale as a sale in execution.

The Insolvency Act of 1936 still forms the backbone of South African insolvency law, especially as it relates to consumer debtors but the South African Law Reform Commission started a review of insolvency law in 1987. The last formal report of this commission was published in $2000 .{ }^{122}$ Suffice to say the protection of the family home or primary residence of the insolvent in insolvency as such does not feature in this report.

The question may be asked if the debtor's house (or primary residence) forming part of the estate can be "repurchased" by the insolvent or a family member after sequestration. In theory, and unless the sequestration order is set aside, in which case the estate assets will revert to the insolvent, the insolvent may propose a composition offer to the trustee to be put to the creditors. ${ }^{123}$ If the statutory requirements can be met and if the creditors accept an offer that provided for the insolvent to regain (specific) property, the re-vesting of the house with the insolvent is a possibility. ${ }^{124}$ Usually without an external funder the composition is not an option. Rehabilitation based on a composition as provided for in section 124(3) will re-vest estate property in the insolvent as provided for in the composition. In general, however, after rehabilitation of the insolvent, any estate assets that have not been realised remain vested in the trustee, but the insolvent may apply for a vesting order. ${ }^{125}$

In summary, the position basically is that the continued occupation by the insolvent debtor and his or her dependants following sequestration is in the

118 See s 80 bis of the Insolvency Act.

119 S 82 of the Insolvency Act.

$120 \mathrm{~S} 83(11)$ of the Insolvency Act.

121 Muller v De Wet NO 2001 (2) SA 489 (W) decided that notice of a public auction must be given in the Gazette, whether the creditors have given directions as to the manner of the sale or not.

122 The Report on the Review of the Law of Insolvency Project 63 of 2000, consisting of an Explanatory Memorandum (vol 1) and a proposed Insolvency Bill (vol 2).

$123 \mathrm{~S} 119$ of the Insolvency Act.

$124 \mathrm{~S} 120(2)$ of the Insolvency Act.

125 S 129 (3)(c) of the Insolvency Act read with s 25(1). 
hands of the trustee who should act on the instruction of the creditors in this regard. It is submitted that the mere fact that the insolvent continues to occupy the family home (or rather his or her primary residence) after sequestration will not make the occupation unlawful per se but it will be a factual question if the insolvent has the permission of the Master or the trustee in whom the property vests respectively after sequestration to determine whether or not such occupation is lawful. The trustee in principle, may demand the insolvent (and family members) to vacate. ${ }^{126}$ Should the insolvent refuse to do so, the trustee will have to bring an application for eviction in terms of the PIE Act. ${ }^{127}$

The position of the trustee differs from that of the sheriff in the case of individual attachment and execution procedures since the Insolvency Act makes it clear in section 20(1) that the estate property vests in the trustee. In this respect it must be noted that the trustee has a duty to act in the best interests of the creditors and to realise the property to their benefit. ${ }^{128}$

To conclude, the protection of the family home or primary residence of the insolvent may arise at the time of application of a sequestration order and bar certain special cases ${ }^{129}$ it may arise rather in compulsory sequestration applications by a creditor than in case of voluntary surrender where the debtor applies. Currently, there is a question if the same considerations following developments since the Jaftha judgment also will be relevant and entertained by the court hearing the application should the debtor oppose the application on that basis, but it is submitted that a case can be made. ${ }^{130}$ It is important to note that the court has discretion to grant the sequestration order or not but in principle will grant it when the statutory prescribed requirements are met. The sequestration order however will not be granted if it amounts to an abuse of process and, as in the case of Ntsane, ${ }^{131}$ a court should be hesitant to grant the order if the sole purpose of the creditor applicant is to circumvent the attachment requirements set in the individual execution process or where the remaining debt is disproportionate when compared with the value of the property. Clearly, where the debtor can make a reasonable offer to repay following a debt rearrangement either following a debt review process or otherwise, without the estate being sequestrated, the court also should take that into consideration and must do so since it may be to the advantage of creditors. In order to keep the house this route will be beneficial to the debtor and even to the creditors depending on the facts.

Nevertheless, since this aspect of the sequestration process is not clear, it seems once the final sequestration order is granted the debtor at best may be able to rely for instance on the so-called defences in the PIE Act when confronted with an eviction application by the trustee. ${ }^{132}$ As briefly discussed

${ }^{126}$ See discussion of case law in par 7 and 8 in the forthcoming Part 2.

127 Ibid.

128 See Botha NO v Kies supra par 25.

129 See Jordaan $v$ Jordaan supra but note and as discussed above the case concerned the rights of housing of the ex-wife of the debtor-applicant.

130 Especially in view of the judgment referred to in fn 129.

131 See the discussion in heading 3 above, although it must be noted that Ntsane and Gundwana dealt with the individual debt execution process and not with sequestration.

132 See discussion in par 7 and 8 in the forthcoming Part 2. 
above the insolvent may enter into a composition and may qualify for a revesting of (some) property after rehabilitation but such cases are few and far between. In many instances the primary residence of the debtor will be the only available asset of value to satisfy the debts owed the creditors. The ongoing insolvency review project to date has not addressed directly the rights of housing of an insolvent.

\section{CONCLUSION REGARDING PART 1}

As indicated in the introduction above ${ }^{133}$ South African insolvency law does not provide direct protection for insolvents regarding their family home after sequestration, for instance by excluding it or some of its equity from the insolvent estate, or provide for continued occupation after sequestration as is the case in some other legal systems. ${ }^{134}$

However, in view of section 26 of the Constitution South African law has developed rules to protect the right to housing as guaranteed in the Bill of Rights. ${ }^{135}$ This development was initiated by case law but the genesis remains the basic rights enshrined in the Bill of Rights. The cases dealing with this matter concern the socio-economic rights of persons in particular the right to housing by vulnerable and insolvent debtors whose estates were not sequestrated. It should be clear that many in fact were not eligible for sequestration due to the statutory requirements for this process. The judgments, including those of the Constitutional Court, caused rules of individual attachment and execution to be amended in order to provide for judicial oversight in cases of individual execution of the residence of the debtor. ${ }^{136}$ This development of case law following the important Jaftha judgment resulted in legislative amendments to the high courts' and magistrates' courts procedures dealing with these matters by introducing due process in deciding if execution of the primary residence of the debtor should proceed or not in particular circumstances. Factors to be considered by courts adjudicating such requests are referred to in paragraph 3 above.

As mentioned these procedures currently are not applicable in a sequestration application and the question is if these considerations spill over to sequestration applications and, more importantly for this article, if there are any other measures, which protect vulnerable insolvents faced with the prospect of being rendered homeless after the sequestration of their estates. ${ }^{137}$ It remains a question if a court hearing a sequestration application will consider similar factors such as those argued in cases of applications for attachment and execution in this instance. In a recent case, namely Jordaan $v$ Jordaan, ${ }^{138}$ an application for voluntary surrender did open the door in an indirect way for such an investigation and approach in the future.

\footnotetext{
Heading 1 above

Heading 2 above.

Heading 3 above.

Ibid.

Heading 4 above.

Heading 3 above.
} 
The Insolvency Act prescribes the granting of a sequestration order but it is submitted that a case could be argued on the lines of the Jaftha and subsequent cases should the facts regarding the personal circumstances of the insolvent be similar. In the ambit of the advantage of creditor's principle the respondent-debtor (owner) may argue a case that the sequestration in any event will not be to the advantage of creditors or may indicate alternative arrangements or procedures that could be used in place of a sequestration order. The facts will determine what is or is not possible in this regard.

It seems the protection relating to attachment and execution initially applied to indigent home owners but the courts also had to deal with more affluent property owners, such as those who could afford mortgage bonds over the residences. ${ }^{139}$ In such instances there are the rights of the secured creditors, the mortgagees, and it seemed the courts were reluctant to provide similar protection. On the other hand it must be conceded that a debtor who can afford a mortgage bond may well be in a better financial position than the atypical debtor in the Jaftha matter. After initial hesitation later judgments did consider the plights of those with bonded property as well. It is submitted that the developments in the situation where the debtor's estate is not sequestrated either protects his or her continued occupation of the primary residence and/ or it affords the debtor an opportunity while still in occupation to enter into a debt rearrangement with the debtor at such time when for instance his or her financial position has improved in order to do so. Nevertheless, the measures developed in this instance were designed to prevent the debtor being rendered homeless and courts hearing such cases should seek solutions that protect the debtor as well as the interests of the creditor. It is submitted that this further development in fact strengthens the argument that the same consideration should also be considered at the time of hearing a compulsory sequestration application.

In order to have a fuller understanding of the basic requirements to apply for a sequestration order and its consequences in so far as it may be relevant to the homestead of the debtor, the relevant aspects of insolvency law have also been discussed in paragraph 4 above. This section also forms a link between Part 1 and Part 2 of the article since it is important to bear these principles in mind when considering the position of the debtor at the time of the application for compulsory sequestration of his or her estate as well as the position regarding the estate assets etc. following the granting of a sequestration order since the PIE Act may well become relevant during this phase.

139 Heading 3 and 4 above. 